\title{
Geleneksel Mobilyanın İzlerini Fotoğraflardan Sürmek
}

\author{
İrem BEKAR ${ }^{1 *}$ (1) \\ ORCID 1: 0000-0002-6371-9958 \\ ${ }^{1}$ Karadeniz Teknik Üniversitesi, Mimarlık Fakültesi, İç Mimarlık Bölümü, 61000, Trabzon, Türkiye. \\ *e-mail: irembekar@ktu.edu.tr
}

Öz

Kültürel değerlerimizin tariflenmesinde önemli bir parçayı oluşturan öğelerden biri olan geleneksel mobilyalar, bireysel kimliği belirtmenin yanında, üreten ve kullanan toplumun kültürüne, inancına, toplumsal kimliğine, etnik yapısına dayalı bilgiler de iletebilmektedir. Tüm bu özellikleri ile kültürel birikimi ve etkileşimini temsil eden katmanlardan oluşur. Kullanıcısııın ona kattığı anlam ile hafızada yer edinen mobilyalar, sürekliliği sağlanmadığı sürece zamanla kullanıcısı ile ortadan kaybolur. Bu nedenle mobilyaların nesilden nesile aktarılarak sürdürülebilirliğinin sağlanması önemli bir konudur. Bu aşamada geçmişi anımsatan ve günümüze kadar ulaşamamış değerleri tanıyıp anlayabileceğimiz en etkili seçeneklerden biri fotoğraflardır. Çalışmada Trabzon Beşikdüzü ilçesinde seçilen kişilere ait fotoğraflar üzerine görüşmeler yapılmış ve kişilerin fotoğraflar üzerine kurdurduğu cümleler takip edilmiştir. Bu yolla fotoğraflardaki geleneksel mobilyaların kültürel ve anlamsal açıdan kişilerin hafızalarındaki yeri sorgulanmıs ve fotoğrafların kültürel değerleri aktarmadaki yeri irdelenmiştir. Çalışmanın sonucunda sözlü kültür ve görsel kültürde geleneksel mobilyaların kültürel yaşantıdaki yerleri ve fotoğrafların bu etkileşimdeki önemi ortaya konmuştur.

Anahtar Kelimeler: Geleneksel mobilya, fotoğraf, kültür, sözlü tarih

\section{Tracing Traditional Furniture From Photos}

\begin{abstract}
Traditional furniture can transmit information based on the culture, belief, social identity and ethnic structure of the society. Furniture, which takes a place in the memory with the meaning that the user adds to it, disappears when its continuity is not ensured. Photographs are one of the most effective options that we can recognize and understand the values that remind us of the past and have not reached the present day. In the study, interviews were made on the photographs of the selected people in the Trabzon Beşikdüzü district and the sentences that the people made on the photographs were followed. In this way, the cultural and semantic place of the traditional furniture in the photographs in people's memories was investigated. Thus, the place of traditional furniture in cultural life in oral and visual culture and the importance of photographs in this interaction have been revealed.
\end{abstract}

Keywords: Traditional furniture, photography, culture, oral history

\section{Giriş}

İnsanoğlu varoluşundan bugüne yaşadığı, gördüğü, değer verdiği birçok şeyi kalıcı hale dönüştürme eğiliminde olmuştur. Tarihi çağlarda insanların mağara duvarlarına çizdiği resimler, yazıtlar, kitabeler de bunun bir sonucu olarak ortaya çıkmıştır. Tüm bunlar yaşandığı dönem hakkında geçmişten geleceğe bırakılan bir iz olup ve geçmişi anlamak için günümüzde bir araç olarak kullanılmaktadır. Bu tür yazılı, sesli veya görsel belgelerin tümü geçmişe dair bir belge niteliği taşımaktadır.

Citation/Atıf: Bekar, i. (2021). Geleneksel mobilyanın izlerini fotoğraflardan sürmek. Journal of Architectural Sciences and Applications, 6 (2), 555-563.

DOI: https://doi.org/10.30785/mbud.948437 
Değişen ve gelişen dünya ile birlikte insanların kendini ifade etme biçimleri de değişmiştir. Mağara duvarlarındaki izler zamanla yerini farklı teknik ve materyallere bırakmıştır. Resmi görsel belge olarak kullanan sanatçılar, dönemin önde gelen kişilerin portrelerini, savaşları ya da sokakları resmetmişlerdir. 19. yüzyılda ilerleyen teknoloji ve fotoğraf makinesinin icadı ile ise resimler yerini gerçeğe en yakın görüntünün elde edilebileceği fotoğraflara bırakmıştır. Her ne kadar bulunuşunun ilk yıllarında kullanıcılar resim sanatının dilinden beslenen sanatçılardan olsa da tüm gelişmeler fotoğrafı sanatın dışında bir yöne götürmüştür. Fotoğrafçı, resmin o zamana kadar yapamadığını gözü, parmağı ve makinesi aracılığı ile gerçekleştirmiştir (Dinçok, 2006). Hafızalarda yer edinen birçok görüntü fotoğraf sayesinde kalııı bir hale gelerek birey ve toplumun yaşantısı hakkında görsel belgeler olmuştur. Böylece fotoğraf zamanın bir anını saklayarak onun bundan sonraki anlar tarafından yok edilmesini önleyebilmek için bir aracı görevi üstlenmiştir (Berger, 2017). Bir devir niteliği taşıyan fotoğraf makinesinin icadı ile birlikte olayların ve nesnelerin anılarda ve hafızada yer edinme şekli de değişikliğe uğramıştır.

Fotoğraflar çekildiği döneme ait soyut veya somut birçok kültürel izleri de barındırmaktadır. Geçmişteki sokaklar, sanat eserleri, insanlar, mimari yapılar, gelenek görenekler, kıyafetler gibi birçok kültürel değere fotoğraflar aracılığıyla tanıklık edilebilmektedir. Bu noktada fotoğraflar geçmişin unutulmasını ve bu değerlerin yok olmasını önleyen en önemli araçlardan biri haline gelmiştir. Günümüze kadar ulaşamamış bir yapının geçmişte bulunduğuna dair en somut belge döneminde çekilmiş fotoğraflarıdır. Örneğin 1958 yılında Trabzon'da bulunan Opera binası günümüze kadar ulaşamamış, fakat döneme ait fotoğraflar yapı hakkında görsel bilgi edinebilmemizi mümkün kılmıştır (Şekil 1). Başka bir örnekle 2020 yılında llısu baraj inşaatı projesi ile sular altında kalan Türkiye'nin önemli kültür miras birikimini temsil eden Hasankeyf'e gelecek nesillerin tanıklık edebileceği tek seçenek görsel belgelerdir (Şekil 2). Bu noktada insanların yok olan kültürüne ve kültürünü yansıtan değerlerine tanıklık edebilmesi için fotoğraflar önemli bir yere sahiptir.

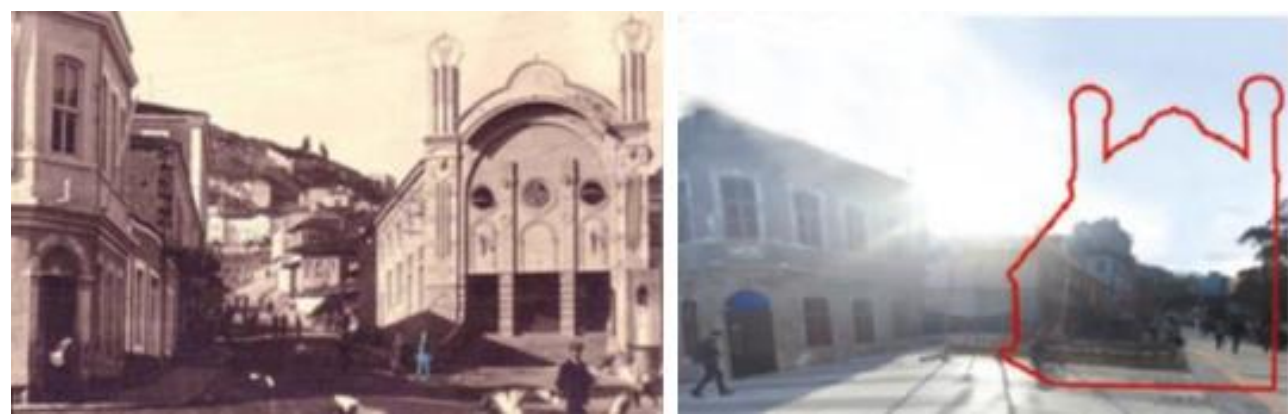

Şekil 1. Trabzon Opera Binası yeri 1958 ve günümüzdeki durumu (Trabzon Opera Binası, 2021)

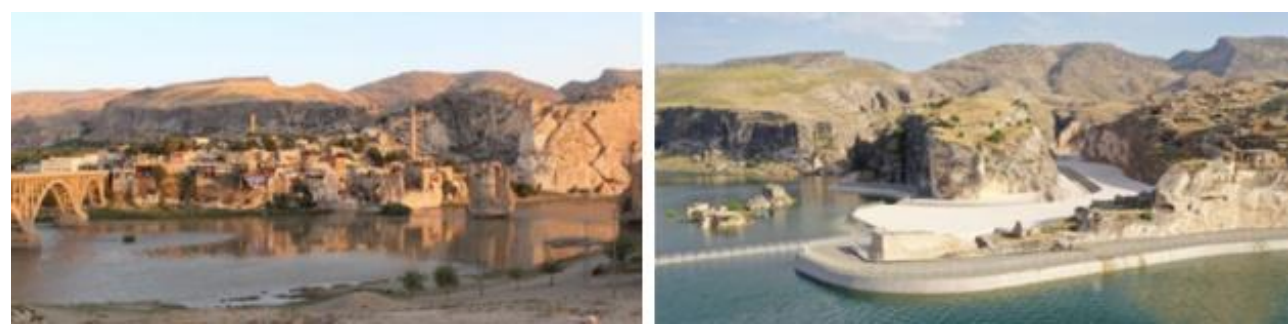

Şekil 2. Hasankeyf önceki durumu ve günümüzdeki durumu (Hasan Söyletmez Arşivi, 2021)

Günümüzün değişen ihtiyaçları, küreselleşme, teknolojik gelişmelerin bir sonucu olarak kültürel değerlerimiz ve toplumların sürdürülebilir yaşamı için hayati olan kültürel üretimler yerlerini artık küresel bağlamda yaygınlaştırılan kitle kültürü örneklerine bırakmaktadırlar (Murtezaoğlu, 2012). Bunlar arasında kültürel ve geleneksel temsiliyetlerin önemli bir parçasını oluşturan geleneksel mobilyalar da yer almaktadır. Geçmişe, bölgeye ve bölgede yaşayan topluma ait birçok bilgi edinmemize yardımcı olan geleneksel mobilyalar da dönemsel gelişme ve değişmelerin etkisiyle yerini kitle kültürü mobilyalara bırakması, eskiye ait olan zamanla yok olmaya başlamasına sebep olmuştur. Geçmişin kültür birikimini anlamanın ve tanımanın en doğrudan yolu günümüze ulaşmış örnekleridir. Günümüze ulaşamayan kültürel mirasımızın ise en somut örnekleri geçmişe ait fotoğraflarda gizlidir. En önemli arşiv oluşturma araçlarından biri olan fotoğraflar sayesinde farkına varamayacağımız ya da bildiğimiz ve kitaplarda sayfalarca anlatılan pek çok kültürel ayrıntıyı da görebiliriz (Dinçok, 2006). 
Geçmişte çekilen fotoğraflara bakıldığında fotoğraftaki birçok kültürel unsurun günümüze gelene kadar yok olduğu fark edilmektedir. Günümüze ulaşamayan bu örnekleri anlamak ve tanımak fotoğraflar, yazılı veya sözlü kaynaklar aracılığıyla mümkündür. Bu anlamda görsel kaynakların ve sözlü ifadelerin beraber kullanılması belge niteliğini daha da güçlü kılacaktır.

Çalışmada kültürel değerlerimizin tariflenmesinde önemli bir parçayı oluşturan geleneksel mobilyaların izleri geçmişe ait fotoğraflar üzerinden ele alınmıştır. Bu doğrultuda Trabzon Beşikdüzü ilçesinde seçilen kişi ve fotoğraflar üzerine görüşmeler yapılmış ve kişilerin fotoğraflar üzerine kurdurduğu cümleler takip edilmiştir. Bu yolla fotoğraflardaki geleneksel mobilyaların kişilerin geçmişinde ve yaşantısındaki yeri sorgulanmış, anıların bireysel boyutları göz önünde bulundurularak geleneksel mobilyaların bellekteki karşılığı irdelenmiştir. Çalışmanın sonucunda sözlü kültür ve görsel kültürde geleneksel mobilyaların kültürel yaşantıdaki yerlerini ortaya koymak hedeflenmektedir.

\subsection{Kültürel Gösterge Olarak Geleneksel Mobilyalar}

Insanın varoluşundan itibaren süregelen çevreyi algılama ve anlamlandırması onların eylemlerini ve eylemleri gerçekleştirme biçimlerini etkilemiş ve kültürlerin oluşumunu sağlamıştır (Ertaş Beşir, Sönmez ve Yılmaz, 2019). Toplumların kimlik belirteci olan kültürel temsiliyetler ritüelistik edimlerle tekrarlanarak nesilden nesile aktarılır ve bir toplumun kültürel belleğini oluştururlar (Murtezaoğlu, 2012). Toplumların yaşamlarını devam ettirebilmesi için kültürel değerlerin sürdürülebilirliğinin sağlanması önemli bir konudur. Kültürel göstergeler kişilerin yaşadığı bölge ve kültürel özelliklerinden beslenmektedir.

Mobilyalar, bireysel kimliği belirtmenin yanında, ürünü üreten ve kullanan toplumun, ülkenin kültürüne, inancına, toplumsal kimliğine, etnik yapısına dayalı bilgiler iletebilmektedir. Aynı zamanda mobilyada kullanılan malzemeler ve kullanım şekli de bölgenin iklim, bitki örtüsü ve nem gibi koşulları hakkında veri sağlayabilmektedir (Kutlu ve Ergün, 2020). Genel olarak mobilya, farklılaşma, grupların toplumsal özelliklerine bağıı olarak çeşitli sosyo-kültürel ortamlara göre farklı sistemler oluşturmaktadır. Her grubun, toplumun veya toplum kesiminin yaşama biçiminin özellikleri, bu grubu ya da kesimi diğerlerinden ayırt etmeyi sağlamakta; her toplum kendi özellikleri doğrultusunda mobilyalar üretmektedir (Özçam, 2013). Geleneksel mobilyalar formundan malzemesine, süslemelerinden yapım tekniğine kadar tüm özellikleri bulunduğu ait olduğu toplumun kültürünü yansıtır ve bu özellikleriyle hafızada yer edinirler. Tüm bu özellikler aynı zamanda bölgenin kültürel kimliğini de şekillendirerek mobilyanın insanların hafızalarındaki yerini de özgün kılmaktadır. Assmann (1997), bu farklılaşmayı bireyin, "yatak, iskemle, yemek ve yıkanma takımı, giysi ve alet edevat gibi günlük ve özel eşyalardan, evler, köyler ve kentler, sokaklar, araçlar ve gemilere kadar", kendisini bulduğu, farklı geçmişleri hatırlatan bir zaman dizini ile çevrildiğini öne sürer.
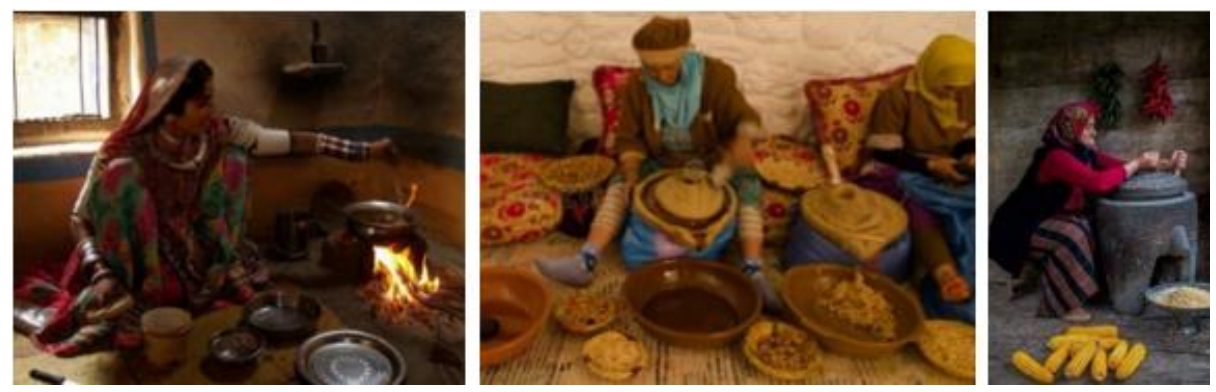

Şekil 3. Hindistan Bölgesi (Shutterstock, t.y.), Marakeş Bölgesi (Dreamstime, t.y.) ve Anadolu Bölgesi'ne (ibrahim Aysündü Arşivi, 2016) ait geleneksel yaşam ve geleneksel mobilya/ürünler

"iç̧inde yaşadığı şeyler dünyasının, şimdiki zamanı yaşarken farklı geçmişleri hatırlatan bir zaman dizini de vardır" (Assmann, 2018). Tüm bunlardan hareketle geleneksel mobilya ve eşyalar kültürel birikimi ve etkileşimini temsil eden katmanlardan oluşur. Kullanıcısının ona kattığı anlam ile anılarda ve hafızalarda yer edinen mobilyalar sürekliliği sağlanmadığı sürece zamanla kullanıcısı ile ortadan kaybolur. Bu nedenle mobilyaların nesilden nesile aktarılarak sürdürülebilirliğinin sağlanması önemli bir konudur. Bu aşamada eskiyi ve geçmişi anımsatan ve günümüze kadar ulaşamamış değerleri tanıyıp anlayabileceğimiz en etkili seçeneklerden biri fotoğraflardır. 


\subsection{Geçmişin Tanıkları Fotoğraflar}

Fotoğraf, gerçekleri açığa çıkarma aracı olarak görülüp, uzun yıllar boyunca birçok olayın veya olgunun tanıklarından biri olmuştur. Bu tanıklık, fotoğrafa olan ilgiyi artıırmış ve fotoğraflar aracılığı ile hafıza köprüleri kurulmuştur (Şahin, 2018). Hafıza yaratmada önemli bir görsel iletişim aracı olan fotoğraf, görüntünün belgelemesi ile birlikte anılar ve yaşanmışlıklar için anımsamanın gerçekçi tanıklığını yapan bir araç olmuştur. Fotoğraf ile akıp giden zamanı, yitip giden hayatları, kültürler, gelenekler kısaca insana ve doğaya dair birçok şey kayıt altına alınır (işlek, 2009). Bir nevi fotoğraflar geçmişin somut bir yansıması haline dönüşür.

Peter Burke 1865 'te çekilen bir fotoğrafı şu sözlerle anlatmaktadır; “...fotoğrafçı Augusto Stahl'ın 1865'lerde çekmiş olduğu bir Rio de Janeiro sokak manzarası, dükkânın içinde ve dışında duran bir grup insanı görüntülemektedir. Grupta yer alan adamlardan birinin şapka takmakla birlikte ayakkabı giymemiş olması, belli bir zaman ve mekânda onun ait olduğu sosyal sınıfın giyim alışkanlıklarının kanıtı olarak görülebilir" (Dinçok, 2006). Bu çerçeveden bakıldığında fotoğraflar ait olduğu döneme dair kültürel, toplumsal, sosyal bilgileri günümüze ve geleceğe aktarmada önemli bir araç olduğunu söylemek mümkündür.

Sontag'a göre, bütün hafızalar bireyseldir ve başka bir şeye indirgenemez (Dinçok, 2006). Buradan yola çıkara fotoğrafların hafızalarda bıraktığı izlerin de kişisel bilgi ve deneyimlerler doğrultusunda çeşitlenebileceğini söylenebilir. Hatırlama, nesnel olmaktan ziyade çağrışımsal, özneldir ve kişiseldir. Fotoğraf, kişisel alan ile bağlantısı ölçüsünde, kişinin bireysel, algısal, duygusal yaşam dünyasıyla, yazılı bir metne kıyasla daha katmanlı bir bağ kurar (Depeli, 2010). Aynı fotoğrafa bakan farklı kişiler o fotoğrafta yer alan unsurları kendi yaşanmışlık ve deneyim süzgecinden geçirerek farklı şekillerde yorumlayabilirler. Bu da fotoğraf ve hafıza arasındaki ilişside kişisel deneyim ve yaşanmışlıkların güçlü etkisinin bir sonucu olarak açıklanmaktadır. Bu doğrultuda bir fotoğraf taşıdığı somut değer ile herkes tarafından kabul edilip bir belge niteliği taşıyabileceği gibi kişinin kendi yaşam alanındaki görsel nesnelerle ilişki kurma ve sürdürme biçimi ve hatırlamanın karmaşık ritmine de tutunabilir (Depeli, 2010). Fotoğrafın kişiler üzerindeki anlamının şekillenmesinde zaman önemli bir faktördür. Bugün baktığımız bir fotoğraf, o an hissettirdiği anlam ile başka zaman karşımıza çıktığında karşııık geldiği anlam farklı olabilir. Burada asıl olan, zaman ve tüm olup bitenler karşısında, hafızamızı ve anılarımızı yitirmeme çabasıdır.

\section{Materyal ve Yöntem}

Çalışmada geleneksel mobilya ve eşyaların kültürel ve anlamsal değerini tarifleyebilmek amacıyla geçmişte çekilmiş fotoğraflardan yola çıkılmıştır. Böylece fotoğrafların kültürel değerleri aktarmada önemine dikkat çekmek ve geleneksel mobilyaların fotoğraflar aracılığıyla kişilerin hafızalarında ve anılarındaki yerini sorgulamak amaçlanmaktadır. Bu doğrultuda çalışma materyalin belirlenmesi, fotoğrafların seçilmesi ve görüşme (sözlü tarih) olmak üzere üç aşamadan oluşmaktadır.

Materyalin belirlenmesi: Çalışmanın örneklem grubu pandemi nedeniyle araştırmacının yakınları arasından belirlenmiştir. Katılımcılar Trabzon Beşikdüzü ilçesi ve burada yaşamış olan kişilerden oluşmaktadır. Beşikdüzü, Trabzon'un batı sınırını oluşturan ve denize kıyısı bulunan bir yerleşim merkezidir. Doğusunda Vakfıkebir, batısında Giresun'a bağlı Eynesil, güneyinde Şalpazarı ve Tonya ilçeleri yer almaktadır.

Fotoğrafların seçilmesi: Çalışmasın bu aşamasında kişiye ait fotoğraflar arasından içerisinde geleneksel mobilya ve eşyaların tespit edildiği örnekler araştırılmıştır. Bu doğrultuda taranan fotoğraflar arasından farklı yıllarda çekilen 8 fotoğraf belirlenmiştir.

Görüşme (sözlü tarih): Sözlü tarih, yazılı belgelere ilave olarak yaşayan kişilerin yaşanmışlıklarına ve anılarına dayalı anlatıları yoluyla yazma ve sıradan insanları, gündelik yaşamı ve öznelliği tarihin araştırma alanına dâhil etme dürtüsüyle şekillenen disiplinler arası bir çalışma alanı ve araştırma yöntemidir (Sözlü tarih, 2021).

Sözlü tarih geleneksel yaşamın ve kişisel hikâyelerin belirlenmesi amacıyla kullanıldığından günümüzde kişisel arşivler önem kazanmaya başlamıştır. Çalışmanın bu aşamasında, belirlenen fotoğraflar 
aracılığıyla fotoğraf sahipleri ile görüşmeler gerçekleştirilerek fotoğrafın nerede, hangi mekânda çekildiğine, fotoğraflardaki mekânın, mobilyaların ve eşyaların kullanımlarına, kişiler için anlamsal değerine ve anı değerlerine yönelik sorular yöneltilmiştir.

\section{Bulgular}

Fotoğraf 1: 1990 senesi yaz aylarında Beşikdüzü Çeşmeönü Mahallesi'nde çekilmiş bir fotoğraftır. Fotoğraf evin mutfak ve oturma alanını ifade eden yaşama alanında geçmektedir. Fotoğrafta 5 çeşit geleneksel mobilya/eşya tespit edilmiştir. Bunlar sini, sini altı, terek, iskemle ve bakır kaplardır (Çizelge 1) Kullanııı ile yapılan görüşmeler sonucunda bu mobilya ve eşyalardan sini, sini altı ve bazı bakır kaplar dışında günümüze ulaşan olmadığı öğrenilmiştir.

Çizelge 1. Fotoğraf 1 analizi

\begin{tabular}{|c|c|}
\hline Fotoğraf 1 & Açıklama \\
\hline Geleneksel mobilya ve eşyalar: & 1.Terek, 2.Örgü iskemle, 3.Sini, 4.Sini altı, 5.Bakır kaplar \\
\hline & $\begin{array}{l}\text { “Yazları kardeşlerim ve ben Beşikdüzü’ne baba evine ziyarete gelirdik. O zamanlar } \\
\text { masa vardı ama annem ve babam siniye alışı olduğu için biz de orada yerdik. Önce } \\
\text { yere bir sofra bezi serilir sonra üzerine sini altı ve sini. Sini alçakta alçak olduğu için } \\
\text { iskemlelerde otururduk. Benim oturduğum iskemleyi babam yapmıştı.”, "Arkada } \\
\text { terek ve içerisinde bakır kap kacaklar var, günümüzün mutfak dolapları aslında ama } \\
\text { kapakları yok. Şu an yok terek yerine bir mutfak dolabı yapıldı” C. Bekar (Kişisel } \\
\text { iletişim, } 3 \text { Mart 2021). }\end{array}$ \\
\hline Fotoğrafın hissettirdiği duygu: & $\begin{array}{l}\text { "Eski zamanlar, annem, babam... Hep birlikte sini etrafında toplanıp yediğimiz } \\
\text { yemekler, samimiyet" C. Bekar (Kişisel iletişim, } 3 \text { Mart 2021) }\end{array}$ \\
\hline
\end{tabular}

Fotoğraf 2: Trabzon'un Beşikdüzü ilçesinin Sis Dağı Yaylası'nda bir yayla evinde çekilen fotoğraf 1992 yaz aylarına aittir. Fotoğraf konutum yaşam alanında geçmektedir. Burası konutta oturma, yeme içme, yatma eylemlerinin gerçekleştiği ortam bir kullanım alanıdır.

Fotoğrafta 5 çeşit geleneksel mobilya/eşya tespit edilmiştir. Bunlar başta yayık olmak üzere iskemle, divan, kuzine ve ibriktir (Çizelge 2). Kullanıcı ile yapılan görüşme sonucunda farklı geleneksel mobilya/eşyalardan de bahsettiği görülmüştür. Bunlar, yük taşımak için kullanılan ve dokuma ipten yapılan dırmaç, altına odun yakarak üstünde yemek yapılmasına yarayan sac ayak ve tahta kaşıktır. Kullanıı ile yapılan görüşmeler sonucunda divan, iskemle, kuzine dışındaki eşyaların kullanım dışı kalarak günümüze ulaşamadığı bilinmektedir.

Çizelge 2. Fotoğraf 2 analizi

\begin{tabular}{|c|c|}
\hline Fotoğraf 2 & Açıklama \\
\hline Geleneksel n & 1.Yayık, 2.İskemle, 3.Divan, 4.Kuzine, 5.İbrik \\
\hline & $\begin{array}{l}\text { “Eskiden ineklerle beraber yaylalara çıkıp yaz boyunca orada kalırdık. Sütten } \\
\text { yoğurt yapıp sonra ahşap yayıkta dakikalarca çalkalayıp yayıp ayran yapardık. } \\
\text { Çocukları da oyalamak için dırmaçla sırtımıza sarardık. Yayığın tereyağı ağaç kaşık } \\
\text { alınırdı. Ayran büyük kazanları alınıp kuzinenin üzerindeki sac ayağın üzerinde } \\
\text { kesilene kadar kaynatılırdı. Yayladaki kahvaltının baş tacı tereyağı süzme ve bakır } \\
\text { ibriklerde kaynatılan suyla çaylar demlenir afiyetle yenilirdi.” E. Bekar (Kişisel } \\
\text { iletişim, } 3 \text { Mart 2021) }\end{array}$ \\
\hline Fotoğrafın hissettirdiği duygu: & $\begin{array}{l}\text { "Bu fotoğraf beni } 30 \text { yıl öncesine götürdü. Önceden doğal ürünler üretilirdi. } \\
\text { Şimdi yağlar fabrikadan sofraya geliyor ve o lezzet asla olmuyor." E. Bekar (Kişisel } \\
\text { iletişim, } 3 \text { Mart 2021) }\end{array}$ \\
\hline
\end{tabular}

Fotoğraf 3: 1996 yılının yaz aylarında Sisdă̆ı'nda bir yayla evinde çekilmiştir. Dış mekânda çekilmiş bir fotoğrafta iki farklı geleneksel mobilya/eşya tespit edilmiştir (Çizelge 3). Bunlar külek ve iskemledir. Yapılan görüşmede kullanıcı fotoğrafı anlatırken yayıktan da bahsetmiştir. İskemle hariç bu mobilya/eşyalardan hiçbiri günümüze ulaşamamıştır. 
Çizelge 3. Fotoğraf 3 analizi

\begin{tabular}{|c|c|}
\hline Fotoğraf 3 & Açıklama \\
\hline Geleneksel mobilya ve eşyalar: & 1. Külek, 2. İskemle \\
\hline & $\begin{array}{l}\text { "25 sene öncesine çekilmiş bir fotoğraf. Eskiden yaz olduğunda ineklerle yaylaya } \\
\text { çıkardık. Arkamdaki tahta kaba külek deriz, onunla ineklere yem verilirdi. Şimdi ne } \\
\text { inek kaldı, ne külek...". "Ineklerden süt alır yayıkta yayar yoğurt, ayran, çökelek } \\
\text { yapardık. Çatının altında asılan şey de çökelek. Artık yapılmıyor hazır alınıyor her } \\
\text { şey.", "Oturduğum iskemleyi kızılağaçtan ben yapmış̧ım. İskemleyi hem içerde } \\
\text { kullanırdık hem de dışarıda." U. Bekar (Kişisel iletişım, } 3 \text { Mart 2021) }\end{array}$ \\
\hline Fotoğrafın hissettirdiği duygu: & $\begin{array}{l}\text { "Büyüklerimizle birlikte yok oldu birçok değerimiz artık sadece fotoğraflardan } \\
\text { hatırlar olduk." U. Bekar (Kişisel iletişim, } 5 \text { Mart 2021) }\end{array}$ \\
\hline
\end{tabular}

Fotoğraf 4: Trabzon'un Beşikdüzü ilçesinin Çeşmeönü Mahallesi'nde dış mekanda çekilen fotoğraf 1990 yılına aittir (Çizelge 4). Kullanıcıyla yapılan görüşme sonucu fotoğraftaki beşiğin 1960 yıllarında üretildiği ve anı değeri nedeniyle yıllarca saklanmış olmasına rağmen günümüze kadar ulaşamadığı bilinmektedir.

Çizelge 4. Fotoğraf 4 analizi

\begin{tabular}{ll} 
Fotoğraf 4 & Açıklama \\
\hline Geleneksel mobilya ve eşyalar: & $\begin{array}{l}\text { 1.Beşik } \\
\text { "30 sene öncesinde çekilmiş bir fotoğraf. Bu beşik benimmiş, benden sonra da } \\
\text { kardeşlerim kullandı. Annem çok uzun süre anıs olduğu için sakladı. Yıllar sonra } \\
\text { benim bir çocuğum olduğunda, hatıra olsun diye bu fotoğrafı çekilmiştik. Gönül } \\
\text { isterdi ki hala duruyor olsun da oğlumun oğluyla da böyle bir fotoğrafı olsaydı. } \\
\text { Nesilden nesile beşik..." U. Bekar (Kişisel iletişim, } 5 \text { Mart 2021) }\end{array}$ \\
\hline Fotoğrafın hissettirdiği duygu: & $\begin{array}{l}\text { "Fotoğraflar bana geçmişi hatırlatıor. Zaman ne çabuk geçiyor." U. Bekar (Kişisel } \\
\text { iletişim, } 5 \text { Mart 2021) }\end{array}$ \\
\hline
\end{tabular}

Fotoğraf 5: Trabzon'un Beşikdüzü ilçesinin Çeşmeönü Mahallesi'nde bir fındık bahçesinde çekilen fotoğraf 1991 yılına aittir. Fotoğrafta o dönem bölgenin geçim kaynaklarından biri olan fındık toplama için kullanılan gıdık ve harar görülmektedir (Çizelge 5). Kullanıcı ile yapılan görüşmeler sonucu bu ürünlerin birçoğunun günümüze ulaşamadığı bilinmektedir.

Çizelge 5. Fotoğraf 5 analizi

\begin{tabular}{|c|c|}
\hline Fotoğraf 5 & Açıklama \\
\hline Geleneksel mobilya ve eşyalar: & 1. Gıdık/Selek, 2.Harar \\
\hline & $\begin{array}{l}\text { "30 sene önce, fındıklıkta çekilmişiz. O zamanlar yazın köye gelir fındık toplardık. } \\
\text { İmeceler de olurdu. Belimize gıdıkları bağlar (yukarı köyde gıdığa selek diyorlar) } \\
\text { fındıkları topladıkça içine atardık. Gıdıklarımız dolunca harar ya da çuvallara } \\
\text { boşaltır, taşıııp harmana sererdik. Hala fındık bahçeleri var ama uzun zamandır } \\
\text { eskisi gibi toplamıyoruz. Gıdık ve harar duruyor hala ama çoğu kullanılacak } \\
\text { durumda değil." G. Bekar (Kişisel iletişim, } 5 \text { Mart 2021) }\end{array}$ \\
\hline Fotoğrafın hissettirdiği duygu: & $\begin{array}{l}\text { "Birlikte imece usulü fındık topladığımız zamanlar, muhabbetler, emekler..." } \\
\text { G. Bekar (Kişisel iletişim, } 5 \text { Mart 2021) }\end{array}$ \\
\hline
\end{tabular}

Fotoğraf 6: Fotoğraf 1993 yılında Sisdağı Yaylası Uzunlar Obası'nda bir yayla evinde çekilmiştir. İç mekân yaşama alanında çekilen fotoğrafta divan ve iskemle olmak üzere iki farklı geleneksel mobilya/eşya tespit edilmiştir (Çizelge 6). Kullanıcıya ait fotoğrafların taraması yapılırken fotoğraf 
6'daki divanın üzerinde farklı yıllarda çekilmiş birçok fotoğraf da bulunmaktadır. Kullanıcı ile yapılan görüşmelerde mekânda ayrıca tahtadan yapılmış bir oturma elemanı olan sedir, ısınma ve yemek pişirme amaçlı kullanılan kuzine ve koyun postundan yapılmış bir seccadeden bahsetmiştir. Bu mobilyalar arasında divan ve iskemleler dışında günümüze ulaşan olmadı̆̆ı bilinmektedir.

Çizelge 6. Fotoğraf 6 analizi

\begin{tabular}{ll}
\hline Fotoğraf 6 & Açıklama \\
\hline Geleneksel mobilya ve eşyalar: & $\begin{array}{l}\text { 1. Divan, 2. İskemle } \\
\text { "Yayla evinde akşam muhabbetimiz kuzine başındaki eski bir divan üzerinde } \\
\text { yetmediği zaman iskemlelere ya da sedire otururduk. İskemleleri kullanmadığımız } \\
\text { zamanlar divanın altında saklardı. Genellikler büyükler divanda küçükler } \\
\text { iskemlede otururlardı. Duvarda asılı koyun postundan yapılmış bir seccade her } \\
\text { daim orada dururdu." E. Bekar (Kişisel iletişim, } 3 \text { Mart 2021) }\end{array}$ \\
\hline Fotoğrafın hissettirdiği duygu: & $\begin{array}{l}\text { "Çok güzel, muhabbetli, sıcak, samimiyet dolu ortamlardı, şimdi o günleri } \\
\text { özlemle anıyorum." E. Bekar (Kişisel iletişim, 3 Mart 2021) }\end{array}$ \\
\hline
\end{tabular}

Fotoğraf 7: 2006 yılında Beşikdüzü'nün Vardallı Mahallesi'nde çekilen fotoğraf bir iç mekânda geçmektedir. Fotoğrafta su değirmeni bulunmaktadır (Çizelge 7). Su değirmeni mısırın öğütülüp un haline getirildiği elemana denmektedir. Kullanıcı görüşmelerinden elde edilen bilgilere göre bu su değirmeni günümüzde hala bulunmakta fakat eskisi kadar aktif bir şekilde kullanılmamaktadır. Ayrıca kullanıcı ile yapılan görüşmelerde başka bir geleneksel ürün olan el değirmeninden de bahsettiği görülmüştür. El değirmeni ise mısırın una göre daha iri parçalar haline getirildiği el gücü ile çalıştırılan küçük taştan yapılmış bir öğütücü araçtır.

Çizelge 7. Fotoğraf 7 analizi

\begin{tabular}{ll}
\hline \multicolumn{1}{c}{ Fotoğraf 7} & \multicolumn{1}{c}{ Açılama } \\
\hline Geleneksel mobilya ve eşyalar: & 1. Su değirmeni \\
\hline & $\begin{array}{l}\text { "Buralarda mısır unu bir evin olmazsa olmazıdır. Toplanan mısırlar kurutulur, yarma } \\
\text { ya da mısır unu yapılırdı. Yarmayı evlerde bulunan el değirmeni ile öğütürdük. Ama } \\
\text { el değirmeni çok ince çekmezdi. Un öğütmek için de çocukken, çuvalları sırtımıza } \\
\text { alır su değirmenine giderdik. Büyükleri kaybettikten sonra su değirmeni kültürümüz } \\
\text { kalmadı, elektrikli değirmenler var ya da her şeyin markette hazırı var artık. Ben } \\
\text { küçükken su değirmenleri daha fazlaydı çevrede, şu an çoğu yok, belki 1-2 tane } \\
\text { kalmıştır." G. Bekar (Kişisel iletişim, 5 Mart 2021) }\end{array}$ \\
\hline Fotoğrafın hissettirdiği duygu: & $\begin{array}{l}\text { "Maziyi hatırlıyorum, annemin bizi değirmene göndermelerini, çocukluğumu...." } \\
\text { G. Bekar (Kişisel iletişim, 5 Mart 2021) }\end{array}$ \\
\hline
\end{tabular}

Fotoğraf 8: Fotoğraf 2010 yılında Sisdağı Yaylası'nda çekilmiştir. Konutun iç mekânında yaşama alanında çekilen fotoğrafta divan ve duvar halısı yer almaktadır (Çizelge 8). Fotoğraf yakın geçmişe ait olduğundan yaklaşık 30-35 yıl geçmişi bu mobilya/eşyalar günümüze ulaşmıştır ve hala kullanılmaktadır. 
Çizelge 8. Fotoğraf 8 analizi

\begin{tabular}{|c|c|}
\hline Fotoğraf 8 & Açıklama \\
\hline Geleneksel mobilya ve eşyalar: & 1. Divan, 2. Duvar halısı \\
\hline & $\begin{array}{l}\text { "Arkamdaki duvar halısı ben doğduğumdan beri orada asıııdır, bildiğim kadarıyla 30- } \\
35 \text { yıllık bir geçmişi var. Küçükken üzerindeki kadın figürlerine bakıp hikâyeler } \\
\text { uydururdum. Dedem en sağdaki kadını hep babaanneme benzetirdi, gülerdik. Hala } \\
\text { o duvar halııını gördüğümde geçmişi, dedem ve babaannemi anarım.", "Yaylaya } \\
\text { gittiğimizde kuzinenin başında divanda otururduk. Akşam olduğunda da yatak } \\
\text { olarak kullanılırlardı." i̇. Bekar (Kişisel iletişim, } 5 \text { Mart 2021) }\end{array}$ \\
\hline Fotoğrafın hissettirdiği duygu: & $\begin{array}{l}\text { "Geçmişi hatırlatıyor bana, çocukluğumu, büyüklerimle yaşadığım anıları." İ. Bekar } \\
\text { (Kişisel iletişim, } 5 \text { Mart 2021) }\end{array}$ \\
\hline
\end{tabular}

Yapılan görüşmelerin sonunda kullanıcılara genel olarak ne hissettikleri sorulduğunda, fotoğraflara bilinçli ya da tesadüfen dâhil olan geleneksel mobilya ve ürünler ile ilgili farkındalığının oluştuğunu ve fotoğrafların geçmişi hatırlatmanın dışında geçmişteki yaşam biçimlerini ve geleneksel mobilyaların bu yaşamlara nasıl dâhil olduğunu da hatırladıklarını belirtmişlerdir. Birçoğu artık kullanılmayan, zamanla kaybolan bu mobilyaların geçmişe dair izleri barındırması ve bu yönüyle aslında ne kadar değerli olduklarını hatırladıkları ortaya çıkmıştır. Günümüz çağının gelişen ve değişen imkânlarının getirdiği yeni yaşam koşulları bizi eskiyi unutmaya ve kültürel izlerimizin kaybolmasına doğru sürüklerken, fotoğrafların hala bu sürece direndiğine yönelik görüşler ifade edilmiştir.

\section{Sonuç ve Öneriler}

Fotoğraflar çekildiği döneme ait soyut veya somut kültürel izler taşımakta ve kullanıcılarının ona kattığı anlam ile değer kazanmaktadır. Bir kültür göstergesi olan geleneksel mobilyaların izlerinin fotoğraflar ve sözlü ifadeler aracılığıyla takip edildiği çalışmanın sonunda elde edilen çıkarımlar aşağıda sıralanmıştır.

- Çalışmada incelenen fotoğraf örneklerinde terek, yayık, divan, iskemle, örgü iskemle, sini, sini altı, bakır kaplar, kuzine, ibrik, külek, beşik, harar, gıdık/selek, su değirmeni ve duvar halısı olmak üzere 16 farklı geleneksel mobilya/ürün tespit edilmiştir. Ayrıca kullanıcı ile fotoğraflar üzerinden yapılan görüşmeler sonucu sac ayak, dırmaç, tahta kaşık ve taş değirmen olmak üzere 4 farklı geleneksel mobilya veya üründen söz etmiştir.

- Katılımcılar ve fotoğraflar Trabzon Beşikdüzü ilçesine ait olduğundan tespit edilen geleneksel mobilya ve eşyalar da o bölgenin kültürel özelliklerinin bir parçasıdır. Bölgenin iklimsel özelliklerinin bir sonucu olarak fındık toplamak için selek ve harar, bölgenin yaşam biçimleri ve alışkanlıkları sonucu yayık, taş değirmen, sini ve sini altı gibi mobilya veya eşyaların tespit edilmesi bunun bir sonucu olarak açıklanmaktadır. Aynı çalışma farklı bir bölgede gerçekleştirildiğinde tespit edilen mobilya ve ürünler bölgeye göre farklılaşacaktır.

- Mobilyaların bir kısmı günümüze ulaşmış olsa da büyük bir çoğunluğu zamanla kaybolmuş ve unutulmuştur. Yapılan görüşmeler sonucu kişilerin unuttukları mobilyaları gördüklerinde geçmişe ve o mobilya ile ilişkin anılarını yeniden hatırlamıştır ve böylece mobilya ile birlikte mobilyanın hafızadaki yeri pekişmiştir. Buradan da fotoğrafların unutulan kültürel değerlerin hatırlanmasındaki ve mobilyaların kültürel belleğin oluşmasındaki önemi ortaya çıkmaktadır.

- Geleneksel mobilya veya ürünlerin fotoğrafa bilinçsiz olarak dâhil olan örnekleri bulunurken sadece bir mobilya veya ürünün de fotoğrafın çekilmesinde bir amaç olabileceği de görülmektedir. Beşik ve su değirmeni buna örnektir. Bunun nedeni mobilyanın kullanıcı açısından ifade ettiği anlamın gücü ve geçmişteki yaşanmışıılara verilen değer ile açıklanmaktadır.

- Fotoğraf seçimi ve incelenmesi sırasında aynı mobilya çevresinde farklı tarihlerde çeşitli sebeplerle (sünnet, toplanma, doğum vb.) birden fazla fotoğrafın olduğu görülmüştür. Bu da bir mobilyanın farklı olay ve durumlara tanıklık ederek farklı bellekte çeşitli şekillerde karşılık bulmasına neden olmaktadır. 
- Geleneksel mobilyaların her biri geçmişteki kültürel birtakım sebeplerin etkisiyle şekillenmiştir. Çocukların geçmişte mısı öğütmek için su değirmenine yollanması, yağ ayran çökelek gibi geleneksel yiyeceklerin yapımı için yayık kullanılması, yaylalarda hayvanlara yem verilmesi için külek kullanılması buna örnektir.

- Her eşya kullanıcısının ona kattığı anlam ve yaşanmışlığıyla beraber var olmaktadır. Bu doğrultuda kullanıcıların mobilyalar ile kurdukları anlamsal bağın mobilyanın bellekteki yerini de belirlediği söylenebilmektedir. Çalışma kapsamında tespit edilen duvar halısı, beşik, sini veya yayık buna en iyi örneklerdir.

\section{Teşekkür ve Bilgi Notu}

Makalede, ulusal ve uluslararası araştırma ve yayın etiğine uyulmuştur. Çalışmada kullanılan anket çalışması Karadeniz Teknik Üniversitesi Fen ve Mühendislik Bilimleri Etik Kurulu'nun 08.09.2021 tarihli ve 17 no'lu kararı ile etik kurallara uygundur.

\section{Kaynaklar}

Assmann, J. (1997). Moses the Egyptian. The Memory of Egypt in Westem Monolheism. Cambridge, MA: Harvard University Press.

Assmann, J. (2018). Kültürel Bellek. İstanbul: Ayrıntı Yayınları.

Berger, J. (2017). Bir Fotoğrafı Anlamak. İstanbul: Metis Yayınları.

Depeli, G. (2010). Görsellik ve kültürel bellek ilişkisi: göçmenin evi. Kültür ve Illetişim, 13(2), 9-39.

Dinçok, D. (2006). Fotoğraf ve bellek (Yüksek lisans tezi). Marmara Üniversitesi, Güzel Sanatlar Enstitüsü, İstanbul.

Dreamstime (t.y.). Muslim women making argan oil in Marrakesh, Erişim adresi (10.03.2021): https://www.dreamstime.com/photos-images/argan-oil-cooperative.html

Ertaş Beşir Ş., Sönmez E. ve Yılmaz B (2019). Action to discourse furniture: contemporary period example. Tasarım Kuram, 15(27), 77-84

Hasan Söyletmez Arşivi (2021). Hasankeyf. Erişim adresi (11.03.2021): https://twitter.com/hasansoylemez/status/1280491576473591811

ibrahim Aysündü Arşivi, (2016). Anadolu ocağı. Erişim adresi: https://www.pinterest.es/pin/563583340862664678/

İşlek, N. (2009). Görsel kültür ve toplumsal bellek bağlamında sayısal fotoğraf estetiği (Lisans tezi). Dokuz Eylül Üniversitesi, Güzel Sanatlar Enstitüsü, i̇zmir.

Kutlu, i. ve Ergün, R. (2020). Geleneksel Anadolu yapılarında ahşap üst örtü gelişiminin değerlendirilmesi. International Journal of Mardin Studies, 1(1), 93-109.

Murtezaoğlu, S. (2012). Kültürel belleğin ritüel yoluyla kuruluşu. Motif Akademi Halkbilimi Dergisi, 5(9), 344-350.

Özçam, I. (2013). Biçim dili ve iletişim ekseninde mobilyanın sembolleşmesi ve günümüz mobilyasının sembolleşmesinde rol oynayan sosyolojik ve teknolojik etkenler (Doktora tezi). MSGSÜ, Fen Bilimleri Enstitüsü, İstanbul.

Shutterstock (t.y.) Experience the excitement of the kitchen in your home. Erişim adresi (15.03.2021): https://www.shutterstock.com/tr/search/traditional+indian+woman+cooking

Şahin, D. (2018). Fotoğraf ve bellek: Shimon Attie, Marcelo Brodsky. Ulakbilge, 6(26), 875.

Trabzon Opera Binası. (2021). Erişim adresi (15.03.2021): https://www.star.com.tr/pazar/kuzeyinakmsikayip-opera-binasi-haber-1276680/

Sözlü Tarih. (2021). In Wikipedia. Erişim adresi:13.04.2021, https://tr.wikipedia.org/wiki/S\%C3\%B6zl\%C3\%BC_tarih 